Acta vet. scand. 1973, 1/, 92-106.

From the Department of Pathology and the Department of Microbiology and Immunology, Veterinary College of Norway, and the National Veterinary Institute, Oslo.

\title{
THE GENERALIZED SHWARTZMAN REACTION IN PIGS INDUCED BY DIET AND SINGLE INJECTION OF DISINTEGRATED CELLS OR PARTIALLY PURIFIED ENDOTOXIN FROM ESCHERICHIA COLI
}

By

Jon Teige jr., Knut Nordstoga, Morten Fjølstad and Inger Nafstad

TEIGE, JON jr., KNUT NORDSTOGA, MORTEN FJØLSTAD and INGER NAFSTAD: The generalized Shwartzman reaction in pigs induced by diet and single injection of disintegrated cells or partially purified endotoxin from Escherichia coli. Acta vet. scand. 1973, 14, 92-106. - Two experiments (Exps. I and II) were performed in pigs to test the effect of disintegrated cells and partially purified endotoxin derived from E. coli. The pigs were fed a diet supplemented with cod liver oil in one group, cod liver oil plus vitamin $\mathrm{E}$ in another group, and only commercial pig food in a third group. After one injection of disintegrated cells in Exp. I, lesions characteristic for generalized Shwartzman reaction (GSR), including hemorrhagic necrosis of the skin developed in the two groups given cod liver oil. A single case was also recorded among the control pigs after injection of a large dose. One injection of partially purified endotoxin in Exp. II gave almost similar results as in Exp. I. These two experiments show that pigs fed relatively high amounts of unsaturated fat are predisposed for the GSR and that vitamin E may, to a certain extent, protect against the development of the reaction.

generalized $S h$ wartzman reaction; pig; endotoxin; Escherichia coli; unsaturated fat; vit a min E.

The generalized Shwartzman reaction (GSR) is a well-known condition in laboratory rabbits where it is classically produced by two intravenous injections of bacterial endotoxin, administered at 24 hrs. interval. In pregnant rabbits and rats, only one injection is necessary, as pregnancy seems effective in "pre- 
paring" the animals for the reaction. Bilateral renal cortical necrosis (BCN), which some authors regard as the pathomorphological criterion of human GSR (Thomas 1959), was originally presumed to occur only in pregnant women (De Navasquez 1935). In domestic animals, the GSR is a relatively unknown condition (Nordstoga 1967), and to the authors' knowledge only one equine case has been reported in association with pregnancy (Nordstoga et al. 1968). The GSR may also be produced experimentally by dietary means, in the absence of endotoxin, when pregnant rabbits or rats are fed a diet containing relatively high amounts of oxidized cod liver oil (McKay \& Wong $1962 \mathrm{a}, \mathrm{b}$, Kaunitz et al. 1962,1963 ). Supplementation of vitamin $E$ prevents the reaction. In pigs, microangiopathy has been produced by similar diets (Grant 1961, Nafstad \& Tollersrud 1970), the vascular lesions being almost identical to those occurring in "Mulberry heart disease" (Grant, Nafstad 1970) and also of the same type as the acute vascular modifications in the GSR.

As the GSR may be readily produced in pigs (Nordstoga \& Fjolstad 1967, 1970), the following experiment was performed to elucidate whether vitamin E-dificient pigs possess an enhanced susceptibility to bacterial endotoxin. Furthermore, as vitamin Edeficiency has been considered a predisposing factor in "Mulberry heart disease" (Nafstad \& Tollersrud), an additional aim was to see if the morphological alterations resembled those accompanying “Mulberry heart".

\section{Experimental animals}

\section{MATERIALS AND ME'THODS}

Experiment I included 24 pigs of Yorkshire race. Experiment II included 19 pigs of Norwegian land race. The average weights of pigs in Exps. I and II were 20 and $13.5 \mathrm{~kg}$, respectively. In Exp. I the pigs were randomly divided into three equal groups (grs. 1, 2 and 3) consisting of eight animals in each group. In Exp. II the pigs were grouped in the same way as in Exp. I, except in group 3 where there were only three animals. The pigs of both experiments were given consecutive numbers (Nos. $1-43$ ).

\section{Experimental diet}

The diets for each group in Exp. I were as follows:

Group 1. Casein $22 \%$, cod liver oil $10 \%$, sugar $15 \%$, potato 
meal $49 \%$, and mineral mixture $4 \%{ }^{\star}$. A vitamin mixture ${ }^{\star \star}$ was also supplied with this diet.

Group 2. The same food constituents as in group 1, but the diet was supplemented with $100 \mathrm{mg}$ tocopherol acetate ${ }^{\star \star \star}$ (oil suspension) per pig per day.

Group 3. Control group (fed commercial pig food $\dagger$ ).

In Exp. II, groups 1 and 2, the casein content of the diet was reduced to $16 \%$, and the potato meal content increased to $55 \%$. The constituents of the diet were otherwise the same as used for the three groups of animals in Exp. I.

The cod liver oil $\dagger \nmid$ was subjected to a silica earth absorption method before incorporation in the diet. In this way, vitamin A was removed and the vitamin $\mathrm{E}$ concentration reduced. In groups 1 and 2, Exp. I, the cod liver oil contained $80 \mu \mathrm{g}$ per g of alphatocopherol.

The cod liver oil in Exp. II contained traces of alpha-tocopherol. The casein $\$$ had an average protein content of $90.0 \%$, based on dry matter. All the pigs were fed twice daily by hand. The cod liver oil was mixed with the other components of the diet at each feeding.

\section{Experimental methods}

Blood samples were taken at two weeks' intervals from the anterior vena cava, for the following examinations: hematocrit value, hemoglobin concentration, glutamate-oxalacetate transaminase (GOT), glutamate-pyruvate transaminase (GPT), lactate dehydrogenase (LDH), and creatine phosphokinase (CPK)\& .

* Contents in per cent: Dicalcium phosphate, 68; sodium chloride, 15, potassium chloride, 10 ; magnesium carbonate, 5 ; ferrous sulphate, 1.5; manganese sulphate, 0.25 ; copper sulphate, 0.1 ; cobalt chloride, 0.05 ; potassium iodide 0.05 ; zinc oxide, 0.2 .

* The following were added, in $\mathrm{mg}$ per $100 \mathrm{~kg}$ feed: Ascorbic acid, 500; nicotinic acid, 1600; calcium pantothenate, 1100; inositol, 400; choline chloride, 35,000; riboflavin, 200; biotin, 20 ; folic acid, 70 ; pyridoxine chloride, 130; thiamine hydrochloride, 200; vitamin $B_{12}, 1$.

* * E. Merck AG, Darmstadt, Germany.

$\dagger$ Produced by P. Larsen, Norway.

†† Produced by J. C. Martens and Co. Ltd., Norway.

$\S$ Produced by Norsk Kasein A/L, Norway.

$\S \S$ Analytical procedures were according to Sigma Technical Bulletins (STB); for GOT and GPT: STB No. 505, 1964, Sigma Frankel (S-F) units; for LDH: STB No. 500, 1960, Berger-Broid (B-B) units; for CPK: STB No. 520, Sigma units of CPK. 
During the feeding period pigs Nos. 7 and 31 died of gastric ulcer hemorrhages, and Nos. 27, 28, 29 and 30 of massive dietetic liver necrosis, No. 32 of heart- and muscle degeneration, and No. 39 of intestinal volvulus. Pig No. 8 was killed and excluded from the experimental study because of locomotive difficulties.

Approx. three months after the beginning of the experiment, each pig in Exp. I was given a single injection of disintegrated cells of hemolytic E. coli into the anterior vena cava. The time for the injection was determined when an enhancement of the serum enzymes and a drop in hematological values, indicating a deficiency of vitamin $\mathrm{E}$, were observed in group 1 (Tollersrud $\&$ Nafstad 1970, Baustad \& Nafstad 1968) (Table 1). The doses used in Exps. I and II are shown in Table 2.

T a b l e 1. The clinical-biochemical and hematological values before the toxin injection.

\begin{tabular}{|c|c|c|c|c|c|c|c|c|c|c|c|c|}
\hline \multirow[b]{2}{*}{ Exps. } & \multicolumn{2}{|c|}{ LDH } & \multicolumn{2}{|c|}{ CPK } & \multicolumn{2}{|c|}{ GOT } & \multicolumn{2}{|c|}{ GPT } & \multicolumn{2}{|c|}{ Hemoglobin } & \multicolumn{2}{|c|}{ Hematocrit } \\
\hline & I & II & I & II & I & II & I & II & I & II & $\bar{I}$ & II \\
\hline \multicolumn{13}{|l|}{ Group } \\
\hline 1 & 3300 & 6775 & 64 & 4415 & 43 & 691 & 35 & 137 & 10.5 & 9.6 & 32.8 & 30.7 \\
\hline 2 & 978 & 1278 & 7 & 71 & 36 & 38 & 33 & 24 & 12.5 & 12.1 & 36.9 & 37.0 \\
\hline 3 & 1001 & 1079 & 14 & 33 & 35 & 73 & 44 & 342 & 12.9 & 11.7 & 38.1 & 37.7 \\
\hline
\end{tabular}

The strain of hemolytic Escherichia coli, type 0141: K85 a b used in Exp. I, was isolated from the intestine of pig by the authors. Propagation of the organism was performed by inoculating $1 \mathrm{ml}$ of a $16 \mathrm{hr}$. broth culture into each of 50 Erlenmeyerflasks $(500 \mathrm{ml})$ containing $50 \mathrm{ml}$ solidified $2 \%$ nutrient agar and $50 \mathrm{ml}$ saline. Incubation was carried out in a rotary shaker $\left(150 \mathrm{rev} . / \mathrm{min}\right.$.) at $33^{\circ} \mathrm{C}$ for $48 \mathrm{hrs}$. The liquid contents of the flasks were centrifuged $(10,000 \times \mathrm{g}$ for $20 \mathrm{~min}$.), the sedimented cells washed twice in saline and resuspended in saline to $15 \mathrm{ml}$. The suspension was frozen at $-20^{\circ} \mathrm{C}$. Disintegration of the cells was carried out in an X-Press chamber ${ }^{*}$ by pressing the frozen material three times through a hole having a diameter of $2.5 \mathrm{~mm}$. The disintegrated material was diluted with saline to $33 \mathrm{ml}$. Samples of $1 \mathrm{ml}$ and $2 \mathrm{ml}$ of this diluted suspension were evaporated and dried at $120^{\circ} \mathrm{C}$ until constant weights. The average weight of the two samples was $0.08325 \mathrm{~g}$ dry stubstance per $\mathrm{ml}$

* AB BIOX, Nacka 2, Sweden. 
Table 2. Weights of carcasses, doses used and main necropsy findings in the two experiments.

\begin{tabular}{|c|c|c|c|c|c|c|c|}
\hline Group & $\begin{array}{l}\text { Pig } \\
\text { no. }\end{array}$ & Weight & Dose* & $\begin{array}{l}\text { Died or } \\
\text { killed }\end{array}$ & $\begin{array}{c}\text { Gross le } \\
\text { kidney }\end{array}$ & $\begin{array}{l}\text { ons"* } \\
\text { skin }\end{array}$ & Pathological findings \\
\hline \multirow{7}{*}{$\begin{array}{l}1 \\
\text { (cod } \\
\text { liver } \\
\text { oil) }\end{array}$} & & & & \multirow{7}{*}{$\begin{array}{l}\text { killed } \\
\quad " \\
\Longrightarrow \\
\text { diëd after } \\
6 \text { hrs. } \\
\quad "\end{array}$} & \multicolumn{3}{|l|}{ Exp. I } \\
\hline & 1 & 65 & 0.5 & & 0 & 0 & negative (neg.) \\
\hline & $\mathbf{2}$ & 65 & 0.5 & & + & + & $\mathrm{GSR}^{\dagger}$ \\
\hline & $\overline{3}$ & 55 & 0.75 & & $++t$ & $t+t$ & GSR \\
\hline & 4 & 71 & 0.75 & & ++ & $+t$ & GSR \\
\hline & 5 & 68 & 1.0 & & 0 & 0 & shock \\
\hline & 6 & 61 & 1.0 & & 0 & 0 & $\begin{array}{l}\text { shock. HE }{ }^{\dagger \dagger} \text { : Small amount of } \\
\text { fibrin in many glomeruli }\end{array}$ \\
\hline \multirow{8}{*}{$\begin{array}{l}2 \\
\text { (cod } \\
\text { liver } \\
\text { oil } \\
+ \\
\text { E. vit.) }\end{array}$} & 9 & 66 & 1.0 & killed & 0 & 0 & neg. \\
\hline & 10 & 65 & 1.0 & " & + & + & GSR \\
\hline & 11 & 57 & 1.0 & ", & $t+$ & + & GSR \\
\hline & 12 & 52 & 1.0 & $"$ & + & ++ & GSR \\
\hline & 13 & 68 & 2.0 & ” & $+t$ & $+t$ & GSR \\
\hline & 14 & 55 & 2.0 & $”$ & +++ & $+t+$ & GSR \\
\hline & 15 & 62 & 3.0 & ” & 0 & & HE: Fibrin in some glomeruli \\
\hline & 16 & 63 & 3.0 & $\begin{array}{l}\text { died after } \\
6 \text { hrs. }\end{array}$ & 0 & 0 & $\begin{array}{l}\text { shock. HE: Small amount of } \\
\text { fibrin in many glomeruli }\end{array}$ \\
\hline \multirow{7}{*}{$\begin{array}{l}\quad 3 \\
\text { (control } \\
\text { group) }\end{array}$} & 17 & 49 & 1.0 & killed & 0 & 0 & neg. \\
\hline & 18 & 54 & 1.0 & , & 0 & 0 & HE: Fibrin in few glomeruli \\
\hline & 19 & 49 & 2.0 & ” & 0 & 0 & neg. \\
\hline & 20 & 50 & 2.0 & , & 0 & $\mathbf{0}$ & neg. \\
\hline & 21 & 55 & 4.0 & ” & 0 & 0 & neg. \\
\hline & 22 & 51 & 4.0 & ", & 0 & $\mathbf{0}$ & neg. \\
\hline & $\begin{array}{l}23 \\
24\end{array}$ & $\begin{array}{l}54 \\
55\end{array}$ & $\begin{array}{l}4.5 \\
7.5\end{array}$ & $"$ & $\stackrel{0}{+}+t$ & $\stackrel{0}{t+t}$ & neg. \\
\hline
\end{tabular}

\begin{tabular}{|c|c|c|c|c|c|c|c|}
\hline \multirow{3}{*}{$\begin{array}{l}1 \\
\text { (cod } \\
\text { liver } \\
\text { oil) }\end{array}$} & & & & \multicolumn{3}{|c|}{ Exp. II } & \multirow{3}{*}{$\begin{array}{l}\text { HE: Fibrin in almost all } \\
\text { glomeruli, necrotic tubuli. } \\
\text { HE: Fibrin in few glomeruli, } \\
\text { necrotic tubuli }\end{array}$} \\
\hline & 25 & 41 & 10 & \multirow{2}{*}{$\begin{array}{l}\text { died after } \\
20 \mathrm{hrs} \text {. } \\
\text { killed }\end{array}$} & \multirow{2}{*}{$\begin{array}{l}+ \\
+\end{array}$} & \multirow[t]{2}{*}{0} & \\
\hline & 26 & 53 & 10 & & & & \\
\hline \multirow{5}{*}{$\begin{array}{l}2 \\
\text { (cod } \\
\text { liver } \\
\text { oil } \\
+ \\
\text { E. vit.) }\end{array}$} & 33 & 42 & 10 & \multirow{5}{*}{$\begin{array}{l}\text { killed } \\
\text { ” } \\
\text { died after } \\
20 \text { hrs. } \\
\text { killed }\end{array}$} & \multirow{5}{*}{$\begin{array}{l}+++ \\
++ \\
0 \\
++ \\
+++ \\
++\end{array}$} & \multirow{5}{*}{$\begin{array}{l}+t \\
+ \\
+ \\
++ \\
+++ \\
+++\end{array}$} & GSR \\
\hline & 34 & 46 & 10 & & & & $\begin{array}{l}\text { GSR } \\
\text { HF. Fihrin in many glomeruli }\end{array}$ \\
\hline & $\begin{array}{l}35 \\
36\end{array}$ & 52 & $\begin{array}{l}15 \\
15\end{array}$ & & & & $\begin{array}{l}\text { HE: Fibrin in many glomeruli } \\
\text { GSR }\end{array}$ \\
\hline & & & 20 & & & & GSR \\
\hline & 38 & 48 & 20 & & & & GSR \\
\hline \multirow{3}{*}{$\begin{array}{l}\quad 3 \\
\text { (control } \\
\text { group) }\end{array}$} & 41 & 48 & 20 & killed & $\mathbf{0}$ & 0 & neg. \\
\hline & $\begin{array}{l}42 \\
43\end{array}$ & $\begin{array}{l}52 \\
43\end{array}$ & $\begin{array}{l}40 \\
70\end{array}$ & $”$ & $\begin{array}{l}0 \\
0\end{array}$ & $\begin{array}{l}0 \\
0\end{array}$ & $\begin{array}{l}\text { neg. } \\
\text { HE: Fibrin in few glomeruli }\end{array}$ \\
\hline & & & & & & & HL. Fiorin in lew gomeruin \\
\hline
\end{tabular}

* Doses given: Exp. I $-\mathrm{ml}$ of disintegrated cell suspension

Exp. II - mg of partially purified endotoxin.

* Degree of hemorrhages in the kidney and skin $(0$ to +++$)$.

$\dagger$ GSR: Generalized Shwartzman reaction recorded in both the macroscopical and histological examinations, according to criteria given by Thomas (1959) and McKay (1963).

i† HE: Histological examination. 
Jon Teige jr., Knut Norlstoga, Morten Fjølstad and Inger Nafslad:

The generalized Shwartzman reaction in pigs induced by diet and single injection of disintegrated cells or partially purified endotoxin from Escherichia coli. 

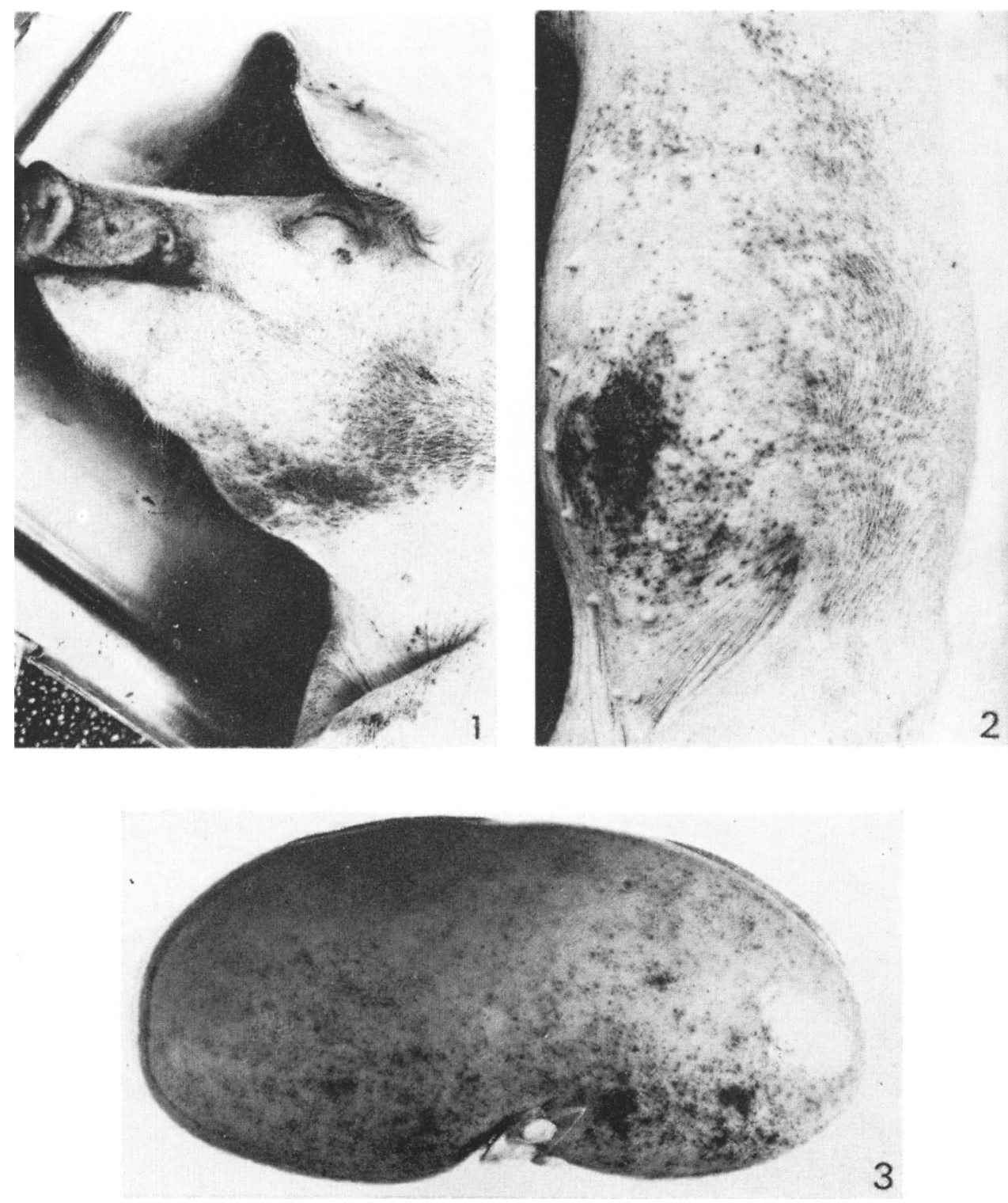

F i g u r e 1. Hemorrhages in the skin of the ventral part of the neck.

Figure 2. Hemorrhages in the skin of the ventral part of the abdomen.

Fig u r e 3. Enlarged kidney with petechial and ecchymotic hemorrhages. 


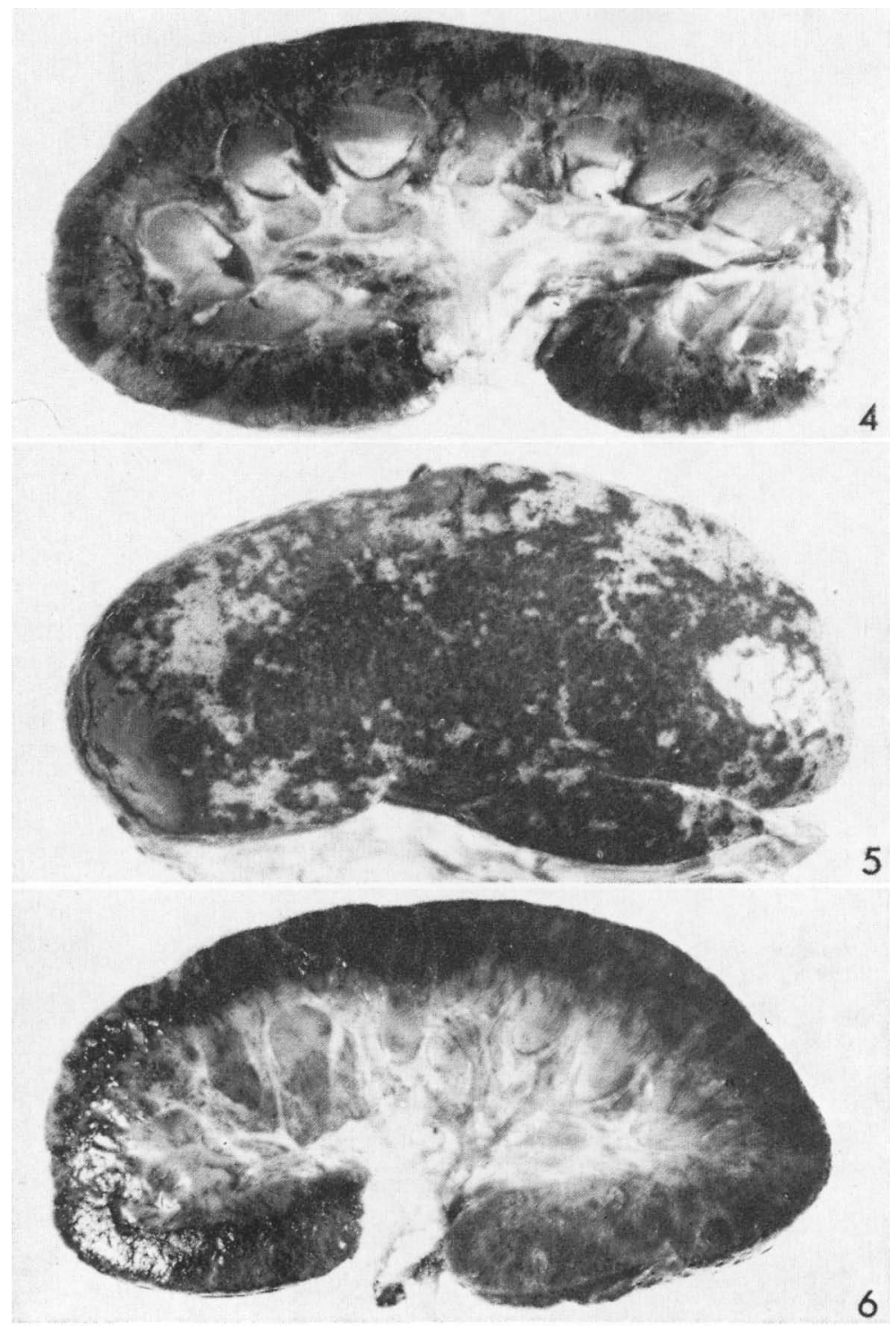

Figure 4. Cut surface of the kidney in Fig. 3. Hemorrhages and necrosis, particularly wide-spread in the juxta medullary portion.

F i g u r e 5. Enlarged kidney with diffuse hemorrhages and necrosis.

F igure 6. Cut surface of the kidney in Fig. 5. Hemorrhages and necrosis in all parts of the cortex. 

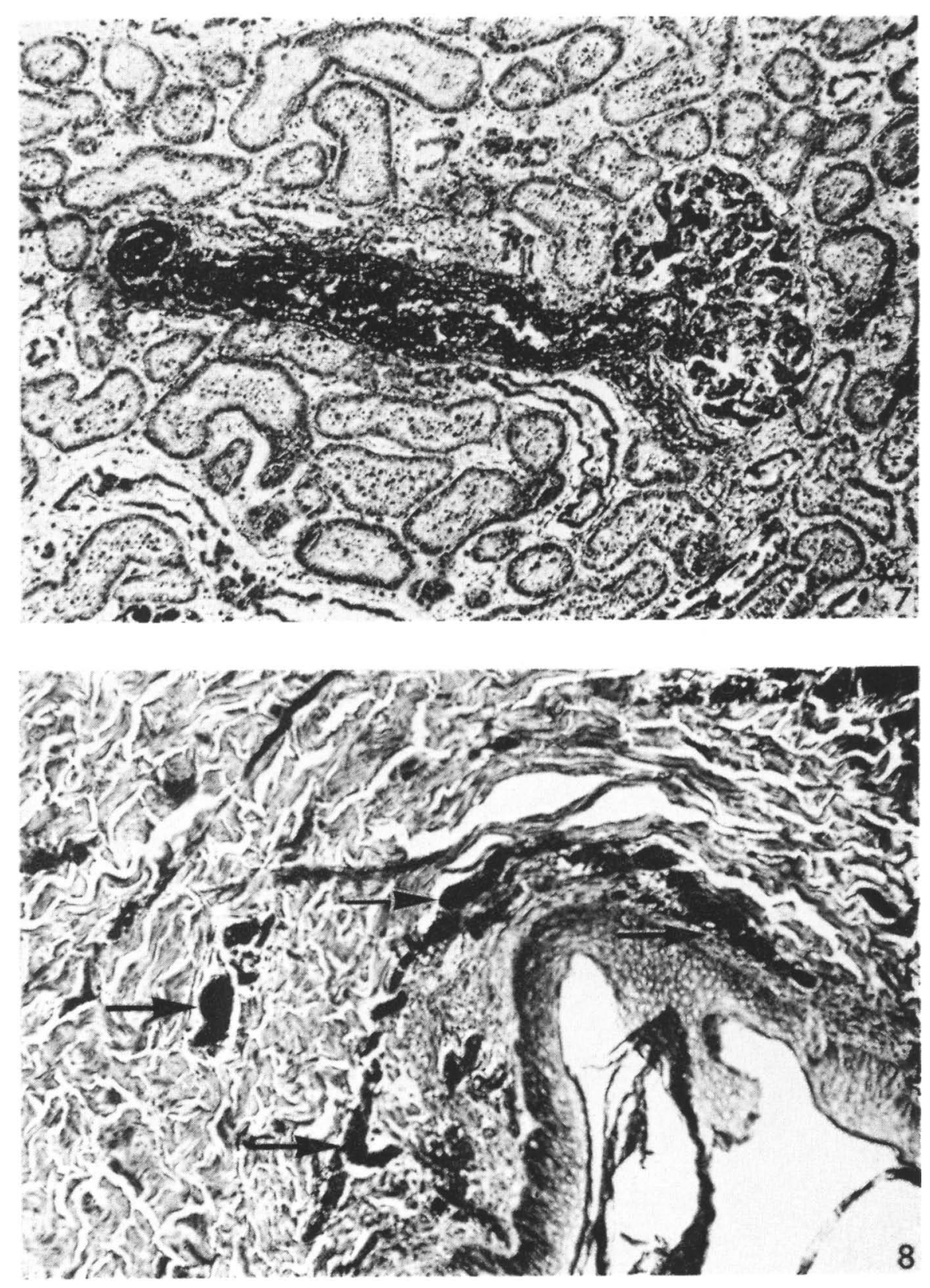

Figure 7. Fibrin deposits in the afferent arteriole and the glomeruli. PTAH. $47 \times$.

F i g u r e 8. Fibrin deposits in small arteries of the corium (arrows). PTAH. $47 \times$. 
suspension. After correcting for added saline it was found that $1 \mathrm{ml}$ suspension contained $0.07843 \mathrm{~g}$ of dried E. coli. The rest of the suspension of disintegrated cells $(30 \mathrm{ml})$ was diluted in saline to $150 \mathrm{ml}$ (thus containing $0.01569 \mathrm{~g}$ dried E. coli per ml suspension) and merthiolate and phenol added to final concentrations of $1: 10,000$ and 5:1000, respectively, and then stored at $4^{\circ} \mathrm{C}$. After four weeks no viable bacteria could be demonstrated in the suspension.

In Exp. II, after a feeding period of about $2 \frac{1 / 2}{2}$ months, each pig was given a single injection of partially purified endotoxin. The endotoxin was a lipopolysaccharide $B$ which was obtained from E. coli type $026: \mathrm{B6}^{*}$.

In Exps. I and II, $48 \mathrm{hrs}$. after the toxin administration the surviving pigs were sacrificed by intravenous injections of pentobarbital (Table 2). Necropsy was performed within an hr. of sacrifice, and tissues collected from kidney, skin, liver, heart- and skeletal muscles, lungs, spleen, intestine, pituitary and adrenal glands were fixed in $10 \%$ buffered formalin for $48 \mathrm{hrs}$. and embedded in paraffin. The sections were stained by the following methods: Hematoxylin and eosin, Elastin van-Gieson and phosphotungstic acid-hematoxylin (PTAH) (Mallory 1942). In Exp. II sections from the heart muscle were also stained with Di-PAS (Pearse 1960) and by the acid picro-Mallory method of Lendrum et al. (1962).

\section{Clinical observations}

\section{RESULTS}

E x p. I. Immediately after the injection of disintegrated cells four pigs (Nos. 21-24) developed a cyanotic appearance and a forced respiration and they had a foamy secretion around the jaws. Two pigs (Nos. 23 and 24) were found to be in an unconscious state for a short time. Half an hr. later pig No. 24 vomited. Screaming, restlessness and convulsions were observed in pigs Nos. 5, 6 and 16 an hr. before death. Pigs Nos. 3-6 and 11-16 lost their appetites while pigs Nos. 23 and 24 had reduced appetites after the injection.

The most striking clinical findings were the alterations in the skin. Some of the pigs (Nos. 3, 13, 14 and 24) exhibited skin alterations about eight hrs. after the injection of disintegrated

* Difco laboratories, Detroit, Michigan, USA. 
cells. These skin lesions were characterized by scattered petechial hemorrhages and slight cyanosis of ears. Within $24 \mathrm{hrs}$. the hemorrhages and cyanosis observed in the skin of the pigs (Table 2) were more or less found to extend on the head and neck (Fig. 1), ventral surface of the abdomen (Fig. 2), in the perineal region and at the distal parts of the extremities.

In three pigs (Nos. 13, 14 and 24) the skin changes were observed almost all over the body. These changes, in addition to the already described hemorrhagic lesions, were also characterized by skin necrosis. The skin alteration aggravated only slightly during the last $24 \mathrm{hrs}$. before euthanasia. During the final hours surviving pigs with skin lesions were in recumbency and had an increased respiratory rate.

E x p. II. The development and extent of the clinical findings in pigs of Exp. II correspond to those of pigs in Exp. I.

\section{Gross lesions}

Table 2 gives a survey of some of the gross and histopathological findings, and the degree of hemorrhages in the skin and kidneys.

E x p. I. Wide-spread subendocardial hemorrhages were observed in pigs Nos. 5, 6 and 16, which also exhibited a slight cyanotic discoloration of the skin. Kidneys with gross lesions were distinctly enlarged. The size was often more than twice the size of the normal, mainly because of an enlarged cortex. The decapsulated surface of the kidney of some of these pigs showed a few petechial and ecchymotic hemorrhages (Fig. 3) associated with many grey stripes and small spots. A narrow subcapsular rim of the kidneys showed minor changes. The cortical parenchyma beneath the narrow subcapsular rim contained numerous hemorrhages of different sizes. The cortical hemorrhages in other pigs with gross kidney lesions were found to be more extensive and in some cases both the surface and the cortical part appeared to be hemorrhagic (Figs. 5 and 6 ). In the medulla only scattered hemorrhages could be observed. The renal lymph nodes appeared to be enlarged and their cut surfaces showed hemorrhages, especially in the marginal zone.

The kidneys of pigs Nos. 5, 15 and 18 were only slightly enlarged. They showed numerous radiating narrow, light-red bands in the juxta medullary region. 
Pigs with kidney and skin changes had moderately enlarged livers. Varying numbers of subpleural hemorrhagic foci and dilated blood vessels in serous membrane of small intestine were also observed in these pigs. The contents of the small intestine were found to be mixed with blood in some cases. An obvious yellow discoloration of the adipose tissue was observed in pigs of group 1.

E x p. II. The gross pathological changes observed in the pigs of Exp. II were similar to those recorded in the pigs of Exp. I.

\section{Histological lesions}

Ex p. I. Pigs with gross kidney lesions (Table 2) showed fibrin thrombi in the lumen of some of the afferent glomerular arterioles (Fig. 7). The walls of the vessels in some cases gave a positive staining reaction for fibrin. Often the glomeruli had a swollen and homogeneous appearance. In the glomerular capillaries fibrin deposits could be demonstrated (Fig. 7). Necrosis in the glomerular tufts could also be observed. Varying degenerative and necrotic changes were found in the tubular epithelium. The substances found in the lumen of the tubules gave a partial staining reaction for fibrin. The interstitial tissue of ten exhibited numerous hemorrhages and necrosis, particularly in the vicinity of the affected tubules. Fibrin was also found in some parts of the interstitial tissue. These renal changes were observed most constantly in the juxta medullary region of the kidney. The fibrin deposits recorded in pigs Nos. 5, 15 and 16 (Table 2) were also limited to this part of the kidney.

Fibrin thrombi were observed in the lumen of the small blood vessels in corium (Fig. 8) together with macroscopical skin lesions in some cases. Occasionally these vessels were found to be surrounded by incipient necrotic tissue.

Dilatation of the perilobular hepatic sinusoides was observed in three pigs (Nos. 5, 6 and 16) (dead of shock). The hepatic sinusoides were found to contain many leucocytes, predominantly neutrophils and also some eosinophils in pigs with kidney and skin lesions. Proliferation of the reticulo-endothelial cells in the liver was observed in pigs of groups 1 and 2.

Incipient hyaline degeneration was recognized in the skeletal muscles of pigs Nos. 5, 6 and 11. A slight granular degeneration in the heart muscles was found in some of the animals in groups 
1 and 2. About half of the number of pigs from all the three groups examined showed thickened pulmonary interalveolar septa associated with infiltration of mononuclear cells.

Histopathological examination of spleen, intestine, pituitary and adrenal glands did not show thrombotic vessels or any other lesions.

E $x$ p. II. The histopathological changes in the kidneys, skin, liver and lungs of pigs in Exp. II corresponded to those changes described for the pigs in Exp. I. Hyaline muscle degeneration appeared in two pigs of group 1 (Nos. 25 and 26) and two pigs of group 2 (Nos. 35 and 38), but the lesions were more extensive in the former. Thrombotic masses, with the staining reaction of fibrin, could be demonstrated in the small vessels of the myocardium in almost all the pigs of Exp. II. Deposition of fibrin was observed in small vessels of the jejunal submucosa of pigs Nos. 26 and 33. No pathological changes were observed in the sections from spleen and pituitary and adrenal glands.

\section{DISCUSSION}

The present studies show that pigs fed relatively high amounts of unsaturated fat are predisposed to the GSR. The pigs react in a similar way as experimental animals which have received agents blocking the RES (Thomas 1952, Thomas \& Good 1952) or animals which are sensitized by pregnancy (McKay 1963).

A single injection of endotoxin may prepare experimental animals for GSR by triggering intravascular coagulation, impairment of reticulo-endothelial phagocytosis, release of adrenergic amines, producing leucocytic aggregation and inhibiting fibrinolytic activity (Müller-Berghaus 1969). One or more of these factors may have been implicated in the present experiments. The effect of dietary lipids on blood coagulation has been the subject of many investigations in rat and man (Mustard \& Murphy 1962, Tompkins et al. 1964, Marcus 1966, Renaud et al. 1966, Jarvis 1967). These investigations, which are concerned with the effect of a lipid diet over a number of weeks, appeared to be rather inconclusive. In pigs Rowsell et al. (1958) found that animals fed butter had a more active clotting system than those fed margarine or a control diet. Dodds \& Miller (1968) observed significant increases in factor VII, fibrinogen and prothrombin levels in a group of miniature pigs fed peanut oil, butter and 
cholesterol for $\mathbf{3 3 0}$ days. Compared to these findings, an effect of the present experimental diet on the coagulation systems seems doubtful, because of its high percentage of unsaturated fatty acids. A possible effect of cod liver oil on the coagulation system in pigs has so far not been investigated, and no conclusion in this respect can be drawn from the present investigation.

Among the major etiological factors of disseminated intravascular coagulation, endothelial damage is most important (Müller-Berghaus). Electronmicroscopic examination of specimens collected from pigs fed almost the same diet and the same quantity of cod liver oil as used in groups 1 and 2 of the present investigation has revealed endothelial injury (Nafstad \& Tollersrud 1970). Submicroscopic endothelial lesions are, therefore, expected to occur in the vitamin $E$ deficient pigs of group 1 in Exps. I and II.

Changes in the fibrinolytic system play an important role in the development of the GSR (Müller-Berghaus). In short-time experiments contradictory results have been obtained in connection with measurements of the fibrinolytic activity after administration of a diet having different fat sources (Greig 1956, Jarvis, Dubber et al. 1967, Neuwissen et al. 1968). The effects of long-term feeding of unsaturated fats on fibrinolysis have, as far as we know, not been investigated. Both endotoxin and later stages of pregnancy depress fibrinolytic activity (Margaretten et al. 1964, Müller-Berghaus). The sensitization of the pigs for GSR in the present experiment may also be due to a decrease in the fibrinolytic activity. Indirectly this suggestion can be supported by the observation that the RES in both pregnant animals and in pigs fed a diet supplemented with cod liver oil seem not to be disturbed (McKay et al. 1964, Teige 1971).

A depressed granulopectic activity was found in rats fed fractions from both fresh and oxidized cod liver oil (McKay et al.). The phagocytic capacity of the RES has also been studied after parenteral injections of lipid, with varying results (McKay et al.). No significant difference in granulopectic activity was measured in dogs fed either saturated, or unsaturated fat (Di Luzio 1960). According to these observations the supply of dietary lipids does not seem to have the same effect in all species. Although the development of GSR in the present experiment may, at least in part, be explained by a blockage of the RES, preliminary measurements of granulopectic activity with 
colloidal carbon seemed not to indicate an impairment of the RES in pigs fed a diet supplemented with cod liver oil (Teige). On the other hand, the RES may have handled the disintegrated cells or the coagulation products of endotoxin in a way other than that of the carbon particles.

The supplementation of vitamin $\mathrm{E}$ increased the resistance of the pigs in Exp. I (Table 2). This finding does not quite correspond to the observation of McKay et al., who also found that the depressing effect of oxidized cod liver oil on the granulopectic activity was completcly neutralized when vitamin $E$ was supplemented to the diet. The amount of tocopherol used in their experiment, however, was much higher than the amount used in the present experiment. On the other hand, the daily supplement of vitamin $E$ as used in this experiment seems to be sufficient to protect the pigs from other diseases, such as Mulberry heart disease, muscle degeneration, and yellow fat disease (Nafstad \& Tollersrud). The sensitizing effect of the diet used in groups 1 and 2 may therefore be due to a specific effect of some of the components present in cod liver oil.

McKay \& Wong (1962 a) fed a diet of oxidized cod liver oil to pregnant rats and were able to elicit the GSR in some of them. Subsequent studies revealed that different oxidized components from oxidized cod liver oil promoted the GSR (McKay \& Wong $1962 \mathrm{a}, \mathrm{b}$, Kaunitz et al. 1962, 1963). As well in these investigations as in the present experiments a fat diet was used as substitute for one endotoxin injection. The sources of the fat, however, were quite different, and the diets in the two experiments also acted in two different ways by precipitating and preparing the animals for the GSR, respectively.

The experimental GSR produced by two consecutive injections of endotoxin is obviously the result of an additive effect of these injections. One efficacious injection of endotoxin with prolonged effect may, theoretically, replace the necessity of the two injections, if the efficacious one is not followed by lethal endotoxin shock. The GSR, after a single injection of disintegrated cells, was observed in one of the pigs (No. 24) in the control group, Exp. I. This is a unique finding, which suggests that the suspension of disintegrated cells of hemolytic E. coli is a very potent "Shwartzman mediator". In this particular pig the presence of cell debris in addition to endotoxin in the suspension may be of importance, as the substitution of the first injection by parti- 
culate matters in experimental GSR has been known for many years (Thomas 1952). The particles may possibly exert their effect by blocking the RES.

Pigs thought to be predisposed to "Mulberry heart" show high values in the level of serum enzymes together with tissue damage (Nafstad \& Tollersrud, Tollersrud \& Nafstad 1970). The low values of the serum enzymes recorded in the pigs of the present experiment indicate therefore minor tissue damage (Table 1) and probably a low degree of predisposition for "Mulberry heart". Dietetic microangiopathy wihch is characterized by mural thickening and by partial obstruction of the vessels, is one of the typical pathomorphological expressions of "Mulberry heart" (Grant 1961, Nafstad \& Tollersrud, Nafstad 1970). The gross pathological changes characteristic of "Mulberry heart", i.e. extensive hemorrhages in the right myocardium, were not observed in the pigs of the present experiments although the myocardial vascular lesions similar to those in dietetic microangiopathy were observed in all three groups of Exp. II. It is, therefore, reasonable to assume that endotoxin is not a factor which can precipitate the characteristic lesions of "Mulberry heart' in pigs.

\section{ACKNOWLEDGEMENTS}

The authors wish to thank Dr. S. Tollersrud for performing the serum enzyme determinations and M. Rafiquzzaman, Senior Lecturer, for his linguistic assistance.

\section{REFERENCES}

Baustad, B. \& I. Nafstad: Anemi hos voksende griser ved E-vitaminmangel. (Anemia in growing pigs with vitamin E-deficiency). Medlemsbl. norske Vet.-foren. 1968, 20, 82.

De Navasquez, S.: Experimental tubular necrosis of the kidneys accompanied by liver changes due to dioxan poisoning. J. Hyg. (Lond.) 1935, 35, 540 548.

Di Luzio, N. R.: Reticuloendothelial involvement in lipid metabolism. Ann. N. Y. Acad. Sci. 1960, 88, 244.

Dodds, W. J. \& K. D. Miller: Dietary-induced atherosclerosis in miniature swine. Hematologic studies: Clotting factors and related hematologic values. Exp. molec. Path. 1968, 8, 263-301.

Dubber, A. H. C., B. Rifkind, M. Gale, G. P. McNicol \& A. S. Douglas: The effect of fat feeding on fibrinolysis "Stypnen" time and platelet aggregation. J. Atheroscler. Res. 1967, 7, 225-235. 
Grant, C. A.: Morphological and aetiological studies of dietetic microangiopathy in pigs ("Mulberry heart"). Acta vet. scand. 1961, 2, Suppl. 3.

Greig, H. B. W.: Inhibition of fibrinolysis by alimentary lipaemia. Lancet 1956, ii, 16-18.

Jarvis, B. W.: Dietary lipids and coagulation. In vitro studies of coagulation mechanism in rats fed hyperlipemic diet. Arch. Path. 1967, 83, 364-369.

Kaunitz, H. E., D. C. Malins \& D. G. McKay: Studies of the generalized Shwartzman reaction produced by diet. II. Feeding of fractions of oxidized cod liver oil. J. exp. Med. 1962, 115, 1127-1136.

Kaunitz, H. E., E. Y. Gauglitz, jr. \& D. G. McKay: Studies of the generalized Scwartzman reaction produced by diet. IV. Ethyl ester fractions of cod liver oil and dihydroxystearic acid. Metabolism $1963,12,371-380$.

Lendrum, A. C., D. S. Fraser, W. Slidders \& R. Henderson: Studies on character and staining of fibrin. J. clin. Path. 1962, 15, 401413.

Mallory, F. B.: Pathological Technique. W. B. Saunders Co., Philadelphia 1942 , p. 76.

Marcus, A. J.: The role of lipids in blood coagulation. Adv. Lipid Res. 1966, 4, 1-37.

Margaretten, W., H. O. Zunker \& D. G. McKay: Production of the generalized Shwartzman reaction in pregnant rats by intravenous infusion of thrombin. Lab. Invest. 1964, 13, 552-559.

McKay, D. G.: A partial synthesis of the generalized Shwartzman reaction. Fed. Proc. 1963, 22, 1373-1379.

McKay, D. G. \& T. C. Wong: Studies of the generalized Shwartzman reaction produced by diet. I. Pathology. J. exp. Med. 1962 a, $115,1117-1126$.

McKay, D. G. \& T. C. Wong: Studies of generalized Shwartzman reaction produced by diet. III. Partial prevention by antibiotics. J. exp. Med. 1962 b, 115, 1137-1140.

McKay, D. G., W. Margaretten \& J. Rothenberg: Blockade of the reticuloendothelial system induced by dietary lipids. Lab. Invest. 1964, 13, 54-61.

Mustard, J.F. \& E. A. Murphy: Effect of different dietary fats on blood coagulation, platelet economy and blood lipids. Brit. med. J. 1962, 1, 1651-1655.

Müller-Berghaus, G.: Pathology of Disseminated Intravascular Coagulation, Disseminated Intravascular Coagulation. F. K. Schattauer Verlag, Stuttgart-New York 1969, 45-61.

Nafstad, I.: Light and electronmicroscopic studies on myocardial vascular injury in vitamin E-deficient pigs. Vet. Path. 1971, 8, $239-255$.

Nafstad, I. \& S. Tollersrud: The vitamin E-deficiency syndrome in pigs. I. Pathological changes. Acta vet. scand. 1970, 11, 452480 . 
Neuwissen, O. J. A. Th., H. Ch. Hart \& N. S. E. van Hemel-Rupert: The influence of fats on blood coagulation and fibrinolysis. Thrombos. Diathes. haemorrh. (Stuttg.) 1968, 19, 267-278.

Nordstoga, K.: Spontaneous bilateral renal cortical necrosis in animals. Path. Vet. 1967, 4, 233-244.

Nordstoga, K. \& M. Fjølstad: The generalized Shwartzman reaction and haemophilus infections in pigs. Path. Vet. 1967, 4, 245-253.

Nordstoga, K. \& M. Fjölstad: Porcine salmonellosis. II. Production of the generalized Shwartzman reaction by intravenous injections of disintegrated cells of Salmonella cholerae-suis. Acta vet. scand. $1970,11,370-379$.

Nordstoga, K., O. Sparboe \& M. Stokkan: Generalized Shwartzman reaction including extensive adrenal hemorrhage in a pregnant mare. Nord. Vet.-Med. 1968, 20, 330-337.

Pearse, A. G. E.: Histochemistry. J. \& A. Churchill, Ltd. London 1960, pp. $831-833$.

Renaud, S., C. Allard \& J. G. Latour: Influence of the type of dietary saturated fatty acid on lipemia, coagulation and the production of thrombosis in the rat. J. Nutr. 1966, 90, 433-440.

Rowsell, H. C., H. G. Downie \& J. F. Mustard: The experimental production of atherosclerosis in swine following the feeding of butter and margarine. Canad. med. Ass. J. 1958, 79, 647-654.

Teige, J. jr.: Unpublished data, 1971.

Thomas, L.: The generalized Shwartzman reaction in rabbits infected with group $\mathrm{H}$ hemolytic streptococci. Rheumatic fever. A symposium. In Minnesota Heart Association, Minneapolis, Univ. Minn. Press. 1952, 232-246.

Thomas, L.: The Shwartzman phenomenon and other reactions produced by the endotoxins of Gram negative bacteria. Immunpathology. 1st Int. Symp. ed. P. Grabar \& P. Niescher. Benno Schwabe, Basel, Stuttgart 1959, 325--338.

Thomas, L. \& R. A. Good: Effect of cortisone on Shwartzman reaction, production of lesions resembling dermal and generalized Shwartzman reactions by single injection of bacterial toxin in cortisone-treated rabbits. J. exp. Med. 1952, 95, 409-428.

Tollersrud, S. \& I. Nafstad: The vitamin E-deficiency syndrome in pigs. II. Investigations on serum and tissue enzyme activity. Acta vet. scand. $1970,11,495-509$.

Tompkins, M. J., S. Dayton \& M. L. Pearce: Effect of long-term feedings of various fats on whole blood clotting times in men. J. Lab. clin. Med. 1964, 64, 763-772.

\section{SAMMENDRAG}

Den generaliserte Shwartzmans reaksjon (GSR) hos gris fremkalt ved hjelp av diett og en enkelt injeksjon av knuste bakterier eller delvis renset endotoksin fremstilt av Escherichia coli.

To forsøk (Exp. I \& II) ble utført på gris for å prøve effekten av knuste bakterier og delvis renset endotoksin fremstilt av E. coli. Gri- 
sene var foret med en diet som var tilblandet tran i en gruppe og tran og vitamin $\mathrm{E}$ i en annen gruppe. I kontrollgruppen ble det foret bare med kommersielt grisefor. Etter en injeksjon av knuste bakterier i Exp. I utviklet det seg forandringer karakteristisk for GSR i de to gruppene som fikk trantilskudd i foret. Disse forandringene omfattet også hemorrhagiske hudnekroser. Et enkelt tilfelle av GSR ble også registrert etter injeksjon av en stor dose knuste bakterier blant grisene i kontrollgruppen. En injeksjon av delvis renset endotoksin i Exp. II gav nesten de samme resultatene som i Exp. I. Disse to fors $\emptyset$ kene viser at griser foret med forholdsvis store mengder umettet fett er preparert for GSR og at vitamin $E$ til en viss grad kan beskytte mot at denne reaksjonen utvikles.

(Received April 13, 1972).

Reprints may be requested from: J. Teige jr., Department of Pathology, Veterinary College of Norway, Postboks 8146, Oslo Dep., Oslo 1, Norway. 